\title{
Mechanisms regulating radiosensitivity of glioma stem cells
}

\author{
Minireview
}

Y. LIU', Y. SHEN ${ }^{1}$, T. SUN ${ }^{2, *}$, W. YANG ${ }^{1, *}$

${ }^{1}$ School of Radiological Medicine and Protection, Medical College of Soochow University, Collaborative Innovation Center of Radiation Medicine of Jiangsu Higher Education Institutions, Soochow University, Suzhou, Jiangsu 215123, China; ${ }^{2}$ Neurosurgery and Brain and Nerve Research Laboratory, The First Affiliated Hospital of Soochow University, Suzhou, Jiangsu 215006, China

*Correspondence: sunting1979st@aliyun.com; detachedy@aliyun.com

Received September 16, 2016 / Accepted March 8, 2017

\begin{abstract}
Malignant glioblastoma (GBM) has become a very common and difficult brain tumor given its low cure rate and high recurrence rate. GBMs are resistant to treatments because glioma stem cells (GSCs)/glioma-initiating cells (GICs), a specific subpopulation of GBM, possess properties of tumor stem cells, such as unlimited proficiency, self-renewal, differentiation and resistance to chemotherapy and radiotherapy, and exhibit a very strong DNA repair capability. Radiotherapy has become a preponderant treatment, and researchers have found many significant tumor microenvironmental factors and valuable signaling pathways regulating the GSC radioresistance, including NOTCH, Wnt/ $\beta$-catenin, Hedgehog, STAT3, and PI3K/ AKT/mTOR. Therefore, we seek to boost GSC radiosensitivity through activating or inactivating pathways alone or together to eliminate the likely source of glioma and prolong survival of patients.
\end{abstract}

Key words: glioma stem cells, radiosensitivity, signaling pathways

Malignant glioblastoma (GBM) has become a very common and lethal brain tumor given its low cure rate and high recurrence rate. According to World Health Organization (WHO) classification, GBM can be divided into 4 types. The median survival period of glioma patients with malignant supreme (WHO grade 4 ) is only 12 to 15 months [1]. This rate continues to decrease although adjuvant radiotherapy and chemotherapy are used in addition to surgical operation. One of the reasons for the poor outcomes might be the existence of a fraction of chemoresistant and radioresistant cells called glioma stem cells (GSCs) in glioma. To date, some experts support the notion that GSCs are partly derived from initiating oncogenic mutations and microenvironment changes [2]. However, glioblastoma cells can dedifferentiate to a stem-like phenotype through ionizing radiations (IR) induction [3] or some signaling pathway mutations [4]. Just as their name implies, GSCs exhibit the properties of tumor stem cells, such as high expression of stem cell markers, capacity of self-renewal and long-term proliferation, formation of neurospheres, multi-lineage differentiation and resistance to chemotherapy and radiotherapy.

Surgical resection of GBM is limited by the diversity of tumor sites and shapes, which is a main reason for unsatisfactory therapeutic effects. However, recent studies suggested that radiation therapy might be a novel target treatment strategy although GSCs possesses the characteristics of radiation resistance [5]. GSCs can improve DNA damage repair (DDR) via direct or indirect methods [5]. Therefore, we can achieve our treatment aim by blocking repair and inducing GSCs apoptosis. The tumor microenvironment, such as hypoxia, plays an important role in GSCs stemness and radioresistance. Moreover, numerous signaling pathways are activated or restrained, and some microRNAs (miRs) are aberrantly expressed in GSCs [6]. In this review, we summarize the current knowledge of GSC resistance to radiotherapy and discuss potential radiotherapeutic approaches to target GSCs. 


\section{GSCs markers}

It is necessary to identify the specific surface markers of GSCs for isolating GSCs and designing GSCs-targeted therapies. CD133 is one of the earliest and best characterized GSCs makers [7-10]. To date, various candidate GSCs markers have been discovered, including Nestin $[8,11,12]$, Musashi-1 [11, 13], CD44 [13], L1 cell adhesion molecular (L1CAM) [14, 15], the polycomb protein B-cell-specific moloney murine leukemia virus insertion site-1 (Bmi-1) [16], A2B5 [17], and SRY-related high-mobility-group (HMG)-box protein-2 (Sox2) [18]. These candidate markers are summarized in Table 1.

\section{The effect of radiation type and irradiation manner on GSCs radiosensitivity}

The effect of radiation type on GSCs radiosensitivity. According to the difference of linear-energy-transfer (LET), the energy transferred per unit length of the track, radiation can be divided into two categories. one category is high LET radiation, such as $\alpha$-particles, neutrons, protons, and heavy ions; another category involves low LET radiation, including $\mathrm{X}$-rays, $\gamma$-rays, and $\beta$-particles.

DNA is the principal target for the biologic effects of radiation. Radiation can induce DNA single/double strand break (SSB/DSB). GSCs treated with low LET radiation had strong repair capacity for DSBs, whereas GSCs could not restore available function after treated with high LET radiation [19]. A previous study demonstrated that GSCs resistance to low LET radiation was attributed to the preferential activation of the DNA damage checkpoint response and an increase in DNA repair capacity, because the phosphorylation of checkpoint kinase (Chk) 1, Chk2 and ataxia-telangiectasia-mutated (ATM) proteins were significantly increased in CD133+ GSCs compared with CD133- cells [20]. In addition, $\gamma$-rays induce autophagy in glioma cells, and autophagy inhibitors significantly enhance the radiosensitivity of glioma cells [21]. Thus, some experts put forward the question of whether $\gamma$-radiation- induced autophagy contributes to the GSCs radioresistance. Further investigations confirmed that the induction of autophagy by low LET $\gamma$-rays indeed facilitated CD133+ GSCs radioresistance. In addition, autophagy inhibitors might be employed to enhance GSCs radiosensitivity because autophagy might protect cancer cells against radiation damage by reducing cytoplasmic acidification, providing catabolites that are required for the repair processes and removing toxic molecules [22-24]. Although the relation between checkpoint activation and autophagy induced by low LET radiation in GSCs is currently not understood, a recent report suggested that the activation of ATM following $\gamma$-radiation could lead to the phosphorylation of liver kinase B1 (LKB1) and inhibition of the mammalian target of rapamycin (mTOR) pathway via the ATM/LKB-1/adenosine monophosphate-activated protein kinase (AMPK) pathway, which might contribute to autophagy induction [22].

High LET radiation can kill tumor cells more effectively than low LET radiation $[25,26]$. The superiority of high LET radiation includes the formation of clustered DNA damage in target cells, cell killing with equal effectiveness regardless of the cell cycle stage and oxygen content, and the ability to cause biological damage by direct action. These actions are responsible for the increased relative biological effectiveness (RBE) compared with low LET radiation. Alan et al. reported that proton therapy might be more efficient than conventional $\mathrm{X}$-ray photon therapy for eliminating GSCs in GBM patients because proton therapy could overcome GSCs radioresistance by inducing increased DNA damage and cell apoptosis via producing large amounts of reactive oxygen species (ROS) [27]. With the increase in treatment-resistant patients, these findings are promising for the development of novel treatment regimens using high LET radiation to treat cancer patients.

The effect of irradiation manner on GSCs radiosensitivity. In cancer radiotherapy, the treatment effect of acute irradiation is quite different from that of fractionated irradiation. Fractionated irradiation induces CD133+ GSCs enrichment and treatment resistance compared with acute irradiation [28-30]. Gao et al. found that acute and fraction-

Table 1. Overview of specific surface markers of GSCs recently identified.

\begin{tabular}{|c|c|c|}
\hline Markers & Effect on radiosensitivity of GSCs & References \\
\hline CD133 & $\begin{array}{l}\text { One of the most primary stem cell markers. Reduces survival time and seriously affects the patient's prognosis. Positively correlated } \\
\text { with radioresistance. }\end{array}$ & {$[7-10]$} \\
\hline $\mathrm{CD} 44$ & Positively correlated with radioresistance. & [13] \\
\hline Nestin & $\begin{array}{l}\text { One of the most primary stem cell markers. A strong prognostic marker for decreased overall survival. Negatively correlated } \\
\text { with radioresistance. }\end{array}$ & {$[8,11-13]$} \\
\hline Musashi-1 & Negatively correlated with GSCs radioresistance. & {$[11,13]$} \\
\hline L1CAM & $\begin{array}{l}\text { L1CAM knockdown suppresses growth and enhances GSCs radioresistance via regulating DNA damage checkpoint response. } \\
\text { Negatively correlated with radioresistance. }\end{array}$ & {$[14,15]$} \\
\hline Sox 2 & $\begin{array}{l}\text { Sox } 2 \text { is fundamental for the maintenance of the self-renewal capacity of neural stem cells when they have acquired cancer properties. } \\
\text { Sox } 2 \text { promotes proliferation and induces tumorigenicity. Negatively correlated with radioresistance. }\end{array}$ & {$[13,18]$} \\
\hline Bmi-1 & An independent marker for poor prognosis. Its relation with radioresistance is unclear. & [16] \\
\hline A2B5 & A2B5 expression is required for brain tumor initiation and maintenance, but its relation with radioresistance is unclear. & [17] \\
\hline
\end{tabular}


ated irradiation differentially modulated glioma stem cell division kinetics. Fractionated irradiation-induced GSCs enrichment might result from a shift from asymmetric to symmetric cell division or a fast cell cycle [28]. The frequency of GSCs symmetric division is regulated by growth factors, including insulin growth factor (IGF), epidermal growth factor (EGF) and fibroblast growth factor (FGF) [31]. In the presence of growth factors, the symmetrical division rate increased significantly. Fractionated radiation could generate vast amounts of IGF1 and upregulate IGF1 receptor (IGF1R) expression in quiescent GSCs. High-level IGF1R expression had a dual radio-protective effect because it could not only negatively regulate protein kinase B (AKT)/extracellular signal-regulated kinase (ERK) signal but also induce forkhead box O3a (FoxO3a) activation [31]. Kim and his colleagues reported that cellular signaling from Abelson murine leukemia viral oncogene homolog $(\mathrm{Abl})$ to protein kinase $\mathrm{C} \delta(\mathrm{PKC} \delta)$ is crucial for fractionated irradiation-induced expansion of GSCs populations and acquisition of resistance to anticancer treatments [29]. Moreover, it was demonstrated that fractionated ionizing radiation (2 Gy/day for 3 days) promotes GSCs expansion and resistance to acute irradiation (10 Gy) in both glioma cell lines and patient-derived glioma cells through upregulation of radiation- inducible nitric oxide synthase (iNOS). The results suggested that targeting iNOS in combination with ionizing radiation might increase the efficacy of radiotherapy for glioma treatment [32].

\section{The effect of tumor microenvironmental factors on GSCs radiosensitivity}

GSCs radioresistance was partly attributed to the property of stemness and the reciprocity with other cells in tumor microenvironment. Jamal and his coworkers compared the response of GSCs and non-GSCs irradiated under in vitro and orthotopic transplantation conditions. Under in vitro conditions, no difference was detected between CD133+ and CD133- cells in $\gamma \mathrm{H} 2 \mathrm{AX}$ and 53BP1 foci induction or dispersal after irradiation. However, irradiation of orthotopic xenografts initiated from GSCs resulted in fewer foci in CD133+ cells compared with their CD133-counterparts within the same tumor [33]. These results not only illustrated that the brain microenvironment could preferentially enhance the radioresistance of CD133+ GSCs but also suggested that microenvironment played a vital role in GSCs radioresistance. This finding serves as a reminder that the tumor microenvironment should be taken into account when studying the radiosensitivity of GSCs.

Reciprocity between GSCs and other cells. After coculture with astrocytes, the initial level of radiation-induced $\gamma \mathrm{H} 2 \mathrm{AX}$ foci in GSCs was reduced, and foci dispersal was enhanced. These results suggested that the presence of astrocytes influenced the induction and repair of DNA double-strand breaks. These data indicated that astrocytes could decrease the radiosensitivity of GSCs in vitro via a paracrine-based mechanism and further supported a role for the microenvironment as a determinant of the GBM radioresponse. Chemokine profiling of coculture media identified a number of bioactive molecules, such as IL-4, IL-6, monocyte chemotactic protein (MCP) 3, epithelial neutrophil activating peptide (ENA)-78, insulin-like growth factor binding protein (IGFBP) 3, and osteoprotegerin, which are responsible for GSC phenotype and radioresistance and are not present under standard culture conditions. In addition, coculture also activated the signal transducer and activator of transcription 3 (STAT3) signal pathway to reduce the radiosensitivity of GSCs [34].

Hypoxic microenvironment. The speed of blood vessel formation is reduced compared with the rapid proliferation of solid tumor cells, which creates a hypoxic environment in a region far away from blood vessels. The immediate cellular reaction to this event is the induction of angiogenesis to supply oxygen to the tumor cells, a process mediated by hypoxiainducible factors (HIFs). However, the new capillary system is not efficient to maintain proper oxygen supply to the growing tumor mass; therefore, an $\mathrm{O}_{2}$ gradient within the neoplastic zone is present in all solid tumors. $\mathrm{O}_{2}$ concentrations are significantly reduced in many human cancers compared with the surrounding normal tissue. The median $\mathrm{pO}_{2}$ in glioma is 0.75 to $20 \mathrm{mmHg}$ compared with 100 to $200 \mathrm{mmHg}$ in healthy brain tissue [35].

A hypoxic microenvironment promotes reprogramming towards a cancer stem cell phenotype in non-stem subpopulation, maintains the stemness of GSCs, and induces the expression of stem cells factors, i.e., octamer-binding transcription factor-4 (OCT4) and cellular-myelocytomatosis viral oncogene (c-MYC) [36]. Hypoxia plays a key role in the regulation of the tumor stem cell phenotype through HIF-2a and subsequent induction of special stem cell marker genes, such as mastermind-like protein 3 (Notch pathway), nuclear factor of activated T cells 2 (calcineurin pathway) and aspartate beta-hydroxylase domain-containing protein 2 , which belong to pathways regulating the stem cell phenotype [37]. The identification of novel molecular regulators of cancer stem cells in the hypoxic niche may be used to target the glioblastoma stem cell population. HIF- $1 \alpha$ and HIF-2 $\alpha$ proteins and miR-210 expression increased as hypoxic time increased in GSCs [38]. More significantly, knockdown of miR-210 decreases stemness and enhances the radiosensitivity of hypoxic GSCs, suggesting that miR-210 might be a potential therapeutic target to eliminate GSCs located in hypoxic niches [39].

Mesenchymal differentiation. Proneural (PN) and mesenchymal (MES) GSC subtypes differ significantly in biological characteristics and treatment responsiveness. A shift in a subset of PN GSCs to MES GSCs occurred in long-term serum culture conditions in a tumor necrosis factor (TNF) $\alpha$ /nuclear factor-k-gene binding (NF- $\mathrm{kB})$-dependent manner and was associated with an enrichment in CD44-expressing subpopulations [40,41]. Given that NF- $\mathrm{kB}$ enhances radiosensitivity 
of several glioblastoma cell lines by inducing apoptosis [42], MES subtypes in GSCs might be more radiosensitive than PN GSCs. However, Bhat et al. concluded that MES GSCs were more radioresistant due to stronger restorative function than PN GSCs [41]. Hence, the aberrant mesenchymal differentiation makes GSCs therapy more difficult. To our surprise, an antibody against the MES gene YKL40, an angiogenic factor, combined with irradiation inhibits vascularization and malignancy progression in glioblastoma [43]. In addition, mixed lineage kinase 4 (MLK4) is overexpressed in MES but not $\mathrm{PN}$, which could also enhance radioresistance by acting as an upstream regulator of NF-kB signaling in GSCs [44]. Therefore, MLK4 inhibitor treatment combined with irradiation might be an ideal therapeutic regimen. In summary, to improve treatment effect, we should inhibit the switch from PN to MES GSCs by using some inhibitors of the signal pathways or other methods.

\section{Signaling pathways involved in GSCs radiosensitivity}

MELK-FOXM1-EZH2 axis. Maternal embryonic leucinezipper kinase (MELK) is a member of the snf1/AMPK family of serine/threonine kinases and a direct target of oncoprotein c-JUN in GSCs. MELK reduces radiation-induced apoptosis via binding and phosphorylating the oncogenic transcription factor forkhead box protein M (FOXM) 1 to form the MELK-FOXM1 protein complex in GSCs in a p53-dependent manner [45]. Moreover, enhancer of Zeste homolog 2 (EZH2), the catalytic subunit of Polycomb repressive complex 2, was targeted by the MELK-FOXM1 complex, which subsequently promotes resistance to radiation in GSCs [46]. EZH2 and MELK are co-expressed in GBM, and MELK or FOXM1 contributes to GSC radioresistance by regulation of EZH2. Furthermore, apoptosis in GSCs pretreated with an EZH2 inhibitor was notably increased [46]. Collectively, these findings suggested that the MELK-FOXM1-EZH2 signaling axis might be essential for GSC radioresistance and that MELKFOXM1-driven EZH2 signaling might serve as a therapeutic target in radiation-resistant GBM tumors.

Notch signaling pathway. The Notch signaling pathway plays a crucial part in maintenance and self-renewal of many cancer stem cells, including breast cancer stem cells $[47,48]$ and GSCs [49-57]. The Notch receptor and its ligands are transmembrane proteins with large extracellular domains that consist primarily of epidermal growth factor (EGF)-like repeat domains [53-55]. Transmembrane ligands activate Notch receptors in neighboring cells via ligand-dependent proteolysis [58]. Ligands can accelerate two proteolytic cleavage events through binding in the Notch receptor (including Notch 1-4). The first event is catalyzed by a disintegrin and metalloprotease (ADAM)-family metalloprotease, whereas the other event is mediated by $\gamma$-secretase, which is an enzyme complex that contains presenilin, nicastrin, encoding multipass transmembrane proteins [53-55]. A study demonstrated that proliferation and self-renewal capacity of GSCs obviously decreased after inhibiting the Notch signaling pathway with $\gamma$-secretase inhibitors (GSI) [51]. Moreover, HIF-1 $\alpha$ and HIF-2 $\alpha$ also maintain characteristics of GSCs through competitively binding to the intracellular domain of Notch (NICD) to dynamically regulate the activation of Notch signaling in GSCs depending on different oxygen tensions [50, 56]. HIF-2 $\alpha$ facilitated the maintenance of GSCs through other stemness-related molecules, in which a downstream gene of HIF-2a, OCT-4, is critically involved [57]. Previous studies have revealed that GSCs promoted radioresistance by preferential activation of the DNA damage response [24], but recent studies found that Notch signaling could also enhance radioresistance of glioma stem/progenitor cells $[49,59]$, by impairing radiation-induced protein kinase $\mathrm{B}$ (AKT) activation and upregulating levels of Mcl-1 (a member of $\mathrm{Bcl}-2$ family) proteins [59], rather than altering the DNA damage response of GSCs following radiation. Taken together, using specific inhibitors of the Notch pathway might be a logical therapeutic strategy to decrease GSCs radioresistance.

Wnt- $\beta$-catenin signaling pathway. The Wnt- $\beta$-catenin signaling pathway plays a significant role in regulating multiple biological processes in stem cells and non-stem cells, including human amniotic mesenchymal stem cells [60], keratinocytes [61], and adipose tissue-derived stromal cells [62]. The pathway is also vital in brain tumors [63]. A study demonstrated the radioresistance role of the Wnt- $\beta$-catenin pathway in mouse mammary progenitor cells [64]. Kim et al. reported that Wnt/ $\beta$-catenin signaling was a pivotal downstream mediator of receptor tyrosine kinase (MET) signaling in GSCs. MET overexpression not only maintained the stemness of GSCs and induced radioresistance by itself but is also associated with Wnt/ $\beta$-catenin signaling to sustain GSCs stemness [65]. Nevertheless, Bacco et al. demonstrated that although MET inhibition decreased GSCs radioresistance, the restrain is achieved by reducing AKT-dependent ATM and p21 activity rather than inhibiting Wnt/ $\beta$-catenin signaling [66]. To date, reports about GSCs radioresistance regulated by the Wnt $/ \beta$ catenin signaling pathway are lacking. Therefore, its molecular mechanism must be further explored.

Hedgehog signaling pathway. Hedgehog signaling regulates proliferation and tumorigenesis of various cancers, including medulloblastoma, neuroblastoma and glioblastoma [67]. In mammals, there are three Hedgehog homologues: desert hedgehog (Dhh), Indian hedgehog (Ihh) and sonic hedgehog (Shh). The Shh signal transduction cascade involves membrane proteins PATCHED1 (PTCH1) and SMOOTHENED (SMOH), which can activate glucagon-like immunoreactivity (Gli) transcription factor, the only reliable marker of pathway activity [68]. Furthermore, the hh-Gli signaling pathway is indispensable for proliferation, survival and tumorigenesis of CD133-politive GSCs by acting on its downstream factor cell division cycle (Cdc) $2[69,70]$. However, whether the pathway has a direct or indirect impact on GSCs radioresistance remains ambiguous.

STAT3 signaling pathway. Signal transducer and activator of transcription 3 (STAT3) participates in various cellular process 
and tumorigenesis as a transcriptional regulator. STAT3 associated with $\mathrm{C} / \mathrm{EBP} \beta$ (a transcriptional regulator) synergistically induces the shift from proneural GSCs to mesenchymal GSCs [71], thus malignant levels increase. In addition, STAT3 is required for maintenance of GSCs [72, 73]. The above evidence suggests that the pathway is a novel treatment target. Thus, the activity of STAT3 should be suppressed using specific inhibitors. Yang et al. demonstrated that STAT3 inhibitor a polyphenol AG490 resveratrol (RV) or knockdown therapy with lentivirus carrying shRNA-STAT3 increases survival rates and improves prognosis and radiosensitivity of GSCs through reducing the repair of radiation-induced DNA damage $[74,75]$.

The DNA-dependent protein kinase catalytic subunit (DNA-PKcs). DNA-PKcs is important in the repair of DNA DSBs induced by IR. Evidence indicates that DNA-PKcs are expressed at high levels in surviving and that proliferating GSCs and its knockdown radiosensitizes GSCs by inducing cell autophagy [76]. In addition, another research team elucidated that DNA-PKcs knockdown also induced differentiation and enhanced the radiosensitivity of GSCs [77]. Kang et al. reported that the inhibitor of the epidermal growth factor receptor (EGFR)-AKT-DNA-PKcs pathway Gefitinib enchances radiosensitivity of GSCs via increasing DNA DSBs and disturbing its repair [78]. Taken together, these findings suggested that we could also achieve our treatment goal through suppressing DNA-PKcs activity in GSCs.

Cathepsin L, a lysosomal cysteine proteinase. Cathepsin $\mathrm{L}$ is expressed at high levles in malignant glioma cells, and the Cathepsin L inhibitor radiosensitizes U251 cells by influencing cell cycle and DNA damage via NF- $\kappa B$ signaling $[79,80]$. Furthermore, recent research demonstrated that knockdown of Cathepsin L promoted radiosensitivity of GSCs through inactivation of the DNA damage response (DDR) checkpoints in vitro and in vivo [81]. Thus, targeting Cathepsin $\mathrm{L}$ is a novel attractive therapeutic regimen.

PI3K/AKT/mTOR signaling pathway. The phosphatidylinositol 3-kinase (PI3K)/AKT pathway is activated frequently, leading to radioresistance in glioblastoma cells. Therefore, inhibition of the pathway enhances radiosensitivity by weakening the repair of radiation-induced DNA DSBs/ SSBs in glioblastoma cell lines [82, 83]. To date, reports about the link between this pathway and GSCs radioresistance are limited. A low-dose AKT inhibitor in combination with fractional radiation therapy induces apoptosis and reduces GSCs tumorigenesis through targeting the PI3K-AKT signaling pathway, indicating that the PI3K-AKT pathway had profound meaning and influence on GSCs radiosensitivity [84]. Furthermore, the signaling pathway in combination with another pathway, mTOR, collectively resolved the radioresistance challenge. mTOR is a core molecule in autophagy regulation, and its inactivation initiates autophagy $[85,86]$. Zhuang and his colleague confirmed that rapamycin-induced autophagy promoted GSCs differentiation and radiosensitivity in vitro [87]. Many inhibitors of this signaling have been reported, for example, AZD2014 (mTORc1/mTORc2 inhibitor) [88] and NVP-BEZ235 (PI3k/mTOR inhibitor) [89-91], which could significantly enhance radiosensitivity of GSCs through impairing DSB repair, increasing apoptosis and inducing cell cycle arrest in the radiosensitive phase. Thus, the PI3K/AKT/ mTOR signaling pathway is also a fascinating treatment target for radioresistant glioma in combination with various chemical agents to obstruct this pathway.

Signaling pathways targeted by miRs. With the exception of the above mentioned miR-210, two miRs, miR-153 and miR-146b-5p, are involved in regulating stemness and radiosensitivity of GSCs $[92,93]$. We found that miR-153 was downregulated but its target gene nuclear factor-erythroid 2-related factor-2 (Nrf-2) was upregulated in GSCs. Under low miR-153 expression conditions, the Nrf-2 overexpression could increase glutathione peroxidase 1 (GPx1) transcription and reduces ROS levels, which leading to GSCs radioresistance. miR-153 overexpression increased ROS production and radiosensitization of GSCs, decreased neurosphere formation capacity and stem cell marker expression, and induced differentiation through ROS-mediated activation of p38 mitogen-activated protein kinase (MAPK) in GSCs [92]. Our recent study demonstrated that overexpression of miR-146b-5p regulates the HuR/lincRNAp21/ $\beta$-catenin pathway to reduce the stemness and GSCs radioresistance. LincRNA-p21, a novel regulator of cell proliferation, apoptosis and DNA damage response, is downregulated in several tumor types. LincRNA-p21 negatively regulates the expression and activity of $\beta$-catenin in GSCs. Downregulation of lincRNA-p21 in GSCs resulted from upregulation of $\mathrm{Hu}$ antigen $\mathrm{R}$ (HuR) expression caused by miR-146b-5p downregulation. MiR-146b-5p overexpression increased apoptosis and radiosensitivity, decreased neurosphere formation capacity and stem cell marker expression, and induced differentiation in GSCs [93]. These findings suggest that these miRNA-mediated pathways play an important role in regulating radiosensitivity and stemness of GSCs. Thus, we predict that targeted therapy of the signaling axis could serve as a novel approach in development of therapeutic strategies against glioma. In addition to the above mentioned miRNAs, numerous additional miRNAs regulating stemness, selfrenewal and differentiation of GSCs were reported, including miR-21 [94], miR-451 [95], miR-152 [96], miR-124 and miR-137 [97]. Whether these miRNAs play a role in GSCs radioresistance should be further investigated.

\section{The radiosensitizing effect of specific inhibitors on GSCs}

DNA damage caused by IR potently activates phosphorylation of checkpoint proteins, such as ATM, Rad17, Chk1, and Chk2, which are responsible for repairing damaged DNA by inducing cell-cycle arrest [20]. Thus, we can take advantage of special inhibitors to interfere with the repair process. A previous study suggested that the radiosensitizing effect was not the same in different cell populations by utilizing the inhibitor debromohymenialdisine to enhance radiation 
sensitivity. For instance, the radiosensitizing effect on the radioresistant $\mathrm{CD} 133+$ population was enhanced compared with the CD133- population [76, 98]. Another study demonstrated that GSCs was more sensitive to knockdown of chk1, whereas the radiosensitizing effect of chk2 knockdown did not exhibit a distinct change between GSCs and non-stem glioma cells [99]. GSCs pretreated with KU55933 (an ATM inhibitor) also relieved G1 phase arrest and extended the G2 phase in response to radiation [100]. The specific ATM inhibitor KU-60019 potentially effectively and safely increases radiosensitivity of GSCs with low TP53 expression and PI3K expression [101]. Two mechanisms are involved in DDR after IR; homologous recombination (HR) and non-homologous end joining (NHEJ). Lim et al. utilized the ATM inhibitor to deplete HR and the DNA-PK inhibitor to block NHEJ in GSCs to compare the radiosensitizing effect of these two inhibitors, and the outcome indicated that the former exhibited a stronger radiosensitizing effect than the later [102].

\section{Conclusion and future perspectives}

After decades of study, malignant glioblastoma remains a challenging disease. A large number of clinical trials proved that surgical resection and drug treatment were not effective to overcome the tumor, but adjuvant radiation therapy might be promising for an increasing number of glioma patients. Nevertheless, glioma cells exhibited strong radiation resistance, which was mainly determined by the properties of glioma stem cells. Hence, the real key for the treatment of malignant glioma is to reduce GSCs stemness and radioresistance and

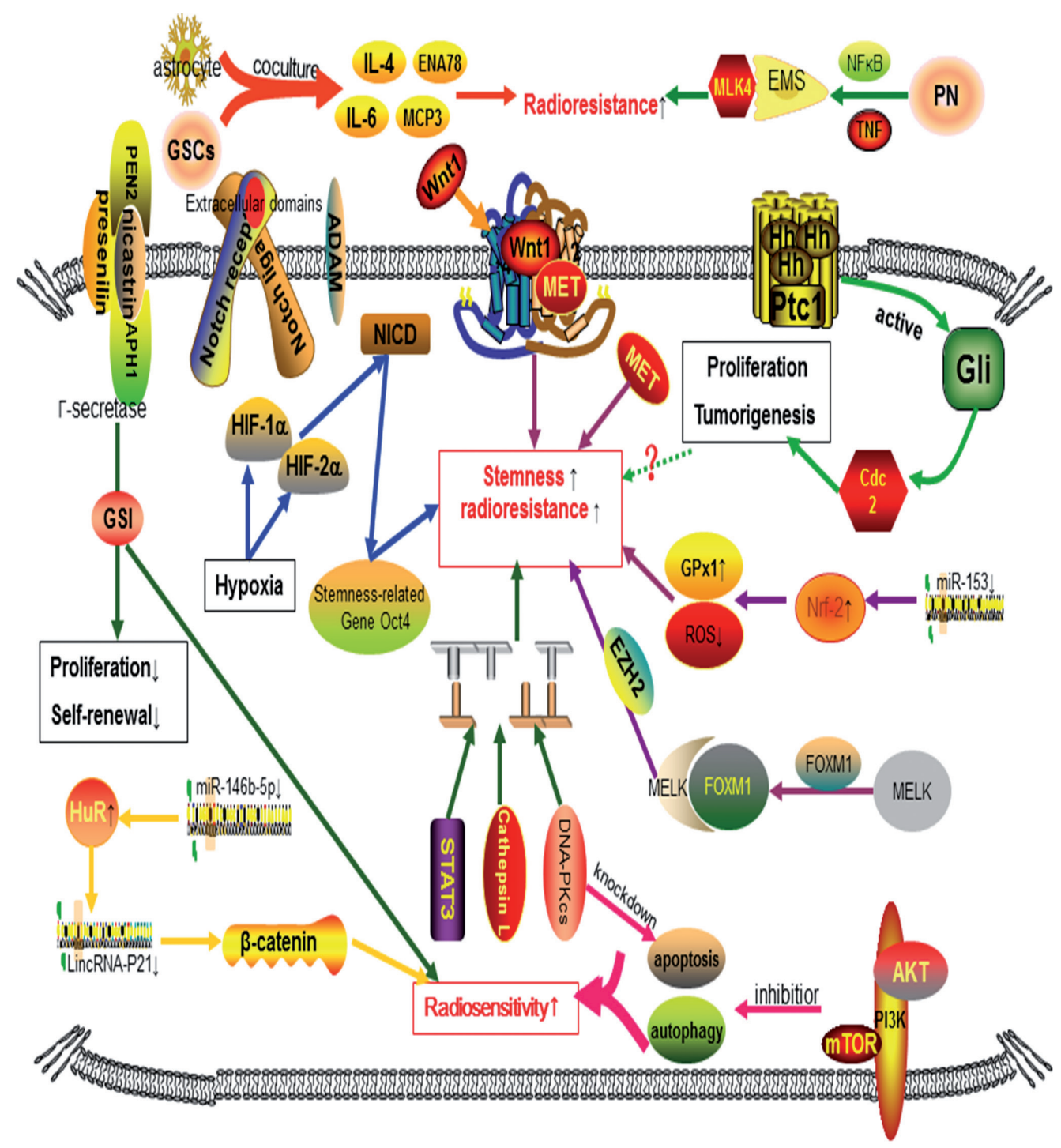

Figure 1. Major mechanisms regulating radiosensitivity of GSCs. 
induce GSCs differentiation. Although GSCs is only a subtle subpopulation of glioma cells, the status of GSCs is decisive and irreplaceable. GSCs radiosensitivity is regulated by multiple signaling pathways, microenvironment factors, and miRNAs. The pathways and regulating factors exhibit mutual communication, not independent communication. In some cases, the synergistic effect of combining radiotherapy with signaling pathway inhibitors exhibited a satisfactory outcome for glioma treatment.

To date, high LET radiation treatment effectiveness for cancer has been recognized by consensus. Therefore, many countries, such as China, Japan and the USA, are now focused on proton and heavy ion research and clinical application. A study reported that proton therapy could improve radiosensitivity in a variety of cancer stem cells (CSCs), including GSCs [22]. Although the therapeutic effect of heavy ion beam on GSCs has not been reported to date, heavy ion beam treatment effectiveness has been confirmed in pancreatic CSCs [103] and breast CSCs [104]. In addition to the high-LET character that exerts increased RBE in tumor cells, proton and heavy ion beams are characterized by an inverse dosedepth profile with a maximal dose deposition in a predefined depth in tissues (Bragg-peak). Thus, the surrounding organs can be spared as much as possible. Therefore, proton and heavy ion beams offer promising physical and biological characteristics and present an alternative treatment option for glioma patients.

Although numerous regulating factors and pathways have been discovered to date (Figure 1), glioma treatment effects remain limited. Thus, we need to identify more updated and more effective therapeutic targets. As long as we wholeheartedly committed to the study of this field, we will elucidate mechanisms regulating the radiosensitivity of GSCs to obtain better treatment outcomes.

Acknowledgements: This work was supported by the National Natural Science Foundation of China (No. 31570851 and 81201742) and Priority Academic Program Development of Jiangsu Higher Education Institutions (PAPD).

\section{References}

[1] PARK DM, SATHORNSUMETEE S, RICH JN. Medical oncology: treatment and management of malignant gliomas. Nat Rev Clin Oncol 2010; 7: 75-77. https://doi.org/10.1038/ nrclinonc.2009.221

[2] DAHAN P, GALA JM, DELMAS C, MONFERRAN S, MALRIC $L$ et al. Ionizing radiations sustain glioblastoma cell dedifferentiation to a stem-like phenotype through survivin: possible involvement in radioresistance. Cell Death Dis 2013; 5: e1543. https://doi.org/10.1038/cddis.2014.509

[3] FIDOAMORE A, CRISTIANO L, ANTONOSANTE A, D’ANGELO M, DI GIACOMO E et al. Glioblastoma Stem Cells Microenvironment: The Paracrine Roles of the Niche in Drug and Radioresistance. Stem Cells Int 2016; 2016: 6809105. https://doi.org/10.1155/2016/6809105
[4] SCHMID RS, SIMON JM, VITUCCI M, MCNEILL RS, BASH $\mathrm{RE}$ et al. Core pathway mutations induce de-differentiation of murine astrocytes into glioblastoma stem cells that are sensitive to radiation but resistant to temozolomide. Neuro Oncol 2016; 18: 962-973. https://doi.org/10.1093/neuonc/nov321

[5] AHMED SU, CARRUTHERS R, GILMOUR L, YILDIRIM S, WATTS C et al. Selective inhibition of parallel DNA damage response pathways optimizes radiosensitization of glioblastoma stem-like cells. Cancer Res 2015; 75: 4416-4428. https:// doi.org/10.1158/0008-5472.CAN-14-3790

[6] CHENG L, BAO S, RICH JN. Potential therapeutic implications of cancer stem cells in glioblastoma. Biochem Pharmacol 2010; 80: 654-665. https://doi.org/10.1016/j.bcp.2010.04.035

[7] PALLINI R, RICCI-VITIANI L, BANNA GL, SIGNORE M, LOMBARDI D et al. Cancer stem cell analysis and clinical outcome in patients with glioblastoma multiforme. Clin Cancer Res 2008; 14: 8205-8212. https://doi.org/10.1158/1078-0432. CCR-08-0644

[8] ZHANG M, SONG T, YANG L, CHEN R, WU L et al. Nestin and CD133: valuable stem cell-specific markers for determining clinical outcome of glioma patients. J Exp Clin Cancer Res 2008; 27: 85. https://doi.org/10.1186/1756-9966-27-85

[9] ZEPPERNICK F, AHMADI R, CAMPOS B, DICTUS C, HELMKE BM et al. Stem cell marker CD133 affects clinical outcome in glioma patients. Clin Cancer Res 2008; 14: 123-129. https://doi.org/10.1158/1078-0432.CCR-07-0932

[10] HE J, SHAN Z, LI L, LIU F, LIU Z et al. Expression of glioma stem cell marker CD133 and O6-methylguanine-DNA methyltransferase is associated with resistance to radiotherapy in gliomas. Oncol Rep 1995; 26: 1305-1313.

[11] STROJNIK T, ROSLAND GV, SAKARIASSEN PO, KAVALAR R, LAH T. Neural stem cell markers, nestin and musashi proteins, in the progression of human glioma: correlation of nestin with prognosis of patient survival. Surg Neurol 2007; 68: 133-143. https://doi.org/10.1016/j. surneu.2006.10.050

[12] MANGIOLA A, LAMA G, GIANNITELLI C, DE BONIS $\mathrm{P}$, ANILE C et al. Stem cell marker nestin and c-Jun NH2terminal kinases in tumor and peritumor areas of glioblastoma multiforme: possible prognostic implications. Clin Cancer Res 2007; 13: 6970-6977. https://doi.org/10.1158/1078-0432. CCR-07-1229

[13] LEMKE D, WEILER M, BLAES J, WIESTLER B, JESTAEDT L et al. Primary glioblastoma cultures: can profiling of stem cell markers predict radiotherapy sensitivity? J Neurochem 2014; 131: 251-264. https://doi.org/10.1111/jnc.12802

[14] BAO S, WU Q, LI Z, SATHORNSUMETEE S, WANG H et al. Targeting cancer stem cells through L1CAM suppresses glioma growth. Cancer Res 2008; 68: 6043-6048. https://doi. org/10.1158/0008-5472.CAN-08-1079

[15] CHENG L, WU Q, HUANG Z, GURYANOVA OA, HUANG $\mathrm{Q}$ et al. L1CAM regulates DNA damage checkpoint response of glioblastoma stem cells through NBS1. EMBO J 2011; 30: 800-813. https://doi.org/10.1038/emboj.2011.10

[16] HAYRY V, TYNNINEN O, HAAPASALO HK, WOLFER J, PAULUS $\mathrm{W}$ et al. Stem cell protein BMI-1 is an independent marker for poor prognosis in oligodendroglial tumours. 
Neuropathol Appl Neurobiol 2008; 34: 555-563. https://doi. org/10.1111/j.1365-2990.2008.00949.x

[17] TCHOGHANDJIAN A, BAEZA N, COLIN C, CAYRE M, METELLUS P et al. A2B5 Cells from Human Glioblastoma have Cancer Stem Cell Properties. Brain Pathol 2010; 20: 211-221. https://doi.org/10.1111/j.1750-3639.2009.00269.x

[18] GANGEMI RM, GRIFFERO F, MARUBBI D, PERERA M, CAPRA MC et al. SOX2 Silencing in Glioblastoma TumorInitiating Cells Causes Stop of Proliferation and Loss of Tumorigenicity. Stem Cells 2009; 27: 40-48. https://doi. org/10.1634/stemcells.2008-0493

[19] HIROTA Y, MASUNAGA SI, KONDO N, KAWABATA S, HIRAKAWA $\mathrm{H}$ et al. High linear-energy-transfer radiation can overcome radioresistance of glioma stem-like cells to low linear-energy-transfer radiation. J Radiat Res 2014; 55: 75-83. https://doi.org/10.1093/jrr/rrt095

[20] BAO S, WU Q, MCLENDON RE, HAO Y, SHI Q et al. Glioma stem cells promote radioresistance by preferential activation of the DNA damage response. Nature 2006; 444: 756-760. https://doi.org/10.1038/nature05236

[21] ITO H, DAIDO S, KANZAWA T, KONDO S, KONDO Y. Radiation-induced autophagy is associated with LC3 and its inhibition sensitizes malignant glioma cells. Int J Oncol 2005; 26: 1401-1410. https://doi.org/10.3892/ijo.26.5.1401

[22] LOMONACO SL, FINNISS S, XIANG C, DECARVALHO A, UMANSKY F et al. The induction of autophagy by $\gamma$-radiation contributes to the radioresistance of glioma stem cells. Int J Cancer 2009; 125: 717-722. https://doi.org/10.1002/ijc.24402

[23] GOZUACIK D, KIMCHI A. Autophagy as a cell death and tumor suppressor mechanism. Oncogene 2004; 23: 2891-2906. https://doi.org/10.1038/sj.onc.1207521

[24] YU L, STRANDBERG L, LENARDO MJ. The selectivity of autophagy and its role in cell death and survival. Autophagy 2008; 4: 567-573. https://doi.org/10.4161/auto.5902

[25] WANG H, WANG Y. Heavier ions with a different linear energy transfer spectrum kill more cells due to similar interference with the $\mathrm{Ku}$-dependent DNA repair pathway. Radiat Res 2014; 182: 458-461. https://doi.org/10.1667/ $\underline{\mathrm{RR} 13857.1}$

[26] YAMAKAWA N, TAKAHASHI A, MORI E, Y IMAI, Y FURUSAWA et al. High LET radiation enhances apoptosis in mutated p53 cancer cells through Caspase- 9 activation. Cancer Sci 2008; 99: 1455-1460. https://doi.org/10.1111/ j.1349-7006.2008.00818.x

[27] ALAN MR, WANG Y, SHAH J, GORDON S, FAGER M et al. Proton beam radiation induces DNA damage and cell apoptosis in glioma stem cells through reactive oxygen species. Sci Rep 2015; 5: 13961. https://doi.org/10.1038/srep13961

[28] GAO X, MCDONALD JT, HLATKY L, ENDERLING H. Acute and fractionated irradiation differentially modulate glioma stem cell division kinetics. Cancer Res 2013; 73: 1481-1490. https://doi.org/10.1158/0008-5472.CAN-12-3429

[29] KIM MJ, KIM RK, YOON CH, AN S, HWANG SG et al. Importance of $\mathrm{PKC} \delta$ signaling in fractionated-radiationinduced expansion of glioma-initiating cells and resistance to cancer treatment. J Cell Sci 2011; 124: 3084-3094. https:// doi.org/10.1242/jcs.080119
[30] OSUKA S, SAMPETREAN O, SHIMIZU T, SAGA I, ONISHI $\mathrm{N}$ et al. IGF1 Receptor Signaling Regulates Adaptive Radioprotection in Glioma Stem Cells. Stem Cells 2013; 31: 627-640. https://doi.org/10.1002/stem.1328

[31] LATHIA JD, HITOMI M, GALLAGHER J, GADANI SP, ADKINA J et al. Distribution of CD133 reveals glioma stem cells self-renew through symmetric and asymmetric cell divisions. Cell Death Dis 2011; 2: e200. https://doi.org/10.1038/ cddis. 2011.80

[32] KIM RK, SUH Y, CUI YH, HWANG E, LIM EJ et al. Fractionated radiation-induced nitric oxide promotes expansion of glioma stem-like cells. Cancer Sci 2013; 104: 1172-1177. https://doi.org/10.1111/cas.12207

[33] JAMAL M, RATH BH, TSANG PS, CAMPHAUSEN K, TOFILON PJ. The Brain Microenvironment Preferentially Enhances the Radioresistance of CD133 + Glioblastoma Stem-like Cells. Neoplasia 2012; 14: 150-158. https://doi. org/10.1593/neo.111794

[34] RATH BH, WAHBA A, CAMPHAUSEN K, TOFILON PJ. Coculture with astrocytes reduces the radiosensitivity of glioblastoma stem-like cells and identifies additional targets for radiosensitization. Cancer Med 2015; 4: 1705-1716. https:// doi.org/10.1002/cam4.510

[35] PATEL A, SANT S. Hypoxic tumor microenvironment: Opportunities to develop targeted therapies. Biotechnol Adv 2016; 34: 803-812. https://doi.org/10.1016/j. biotechadv.2016.04.005

[36] HEDDLESTON JM, LI Z, MCLENDON RE, HJELMELAND $\mathrm{AB}, \mathrm{RICH}$ JN. The hypoxic microenvironment maintains glioblastoma stem cells and promotes reprogramming towards a cancer stem cell phenotype. Cell Cycle 2009; 8: 3274-3284. https://doi.org/10.4161/cc.8.20.9701

[37] SEIDEL S, GARVALOV BK, WIRTA V, VON STECHOW L, SCHANZER A et al. A hypoxic niche regulates glioblastoma stem cells through hypoxia inducible factor 2 alpha. Brain 2010; 133: 983-995. https://doi.org/10.1093/brain/awq042

[38] BAR EE, LIN A, MAHAIRAKI V, MATSUI W, EBERHART CG. Hypoxia Increases the Expression of Stem-Cell Markers and Promotes Clonogenicity in Glioblastoma Neurospheres. Am J Pathol 2010; 177: 1491-1502. https://doi.org/10.2353/ ajpath.2010.091021

[39] YANG W, WEI J, GUO T, SHEN Y, LIU F. Knockdown of miR-210 decreases hypoxic glioma stem cells stemness and radioresistance. Exp Cell Res 2014; 326: 22-35. https://doi. org/10.1016/j.yexcr.2014.05.022

[40] BALASUBRAMANIYAN V, VAILLANT B, WANG S, GUMIN J, BUTALID ME et al. Aberrant mesenchymal differentiation of glioma stem-like cells: implications for therapeutic targeting. Oncotarget 2015; 6: 31007-31017.

[41] BHAT KP, BALASUBRAMANIYAN V, VAILLANT B, EZHILARASAN R, HUMMELINK K et al. Mesenchymal Differentiation Mediated by NF- $\kappa B$ Promotes Radiation Resistance in Glioblastom. Cancer Cell 2013; 24: 331-346. https://doi.org/10.1016/j.ccr.2013.08.001

[42] BERGER R, JENNEWEIN C, MARSCHALL V, KARL $S$, CRISTOFANON $S$ et al. NF- $\kappa B$ is required for Smac mimetic-mediated sensitization of glioblastoma cells for 
$\gamma$-irradiation-induced apoptosis. Mol Cancer Ther 2011; 10: 1867-1875. https://doi.org/10.1158/1535-7163.MCT$\underline{11-0218}$

[43] SHAO R, FRANCESCONE R, NGERNYUANG N, BENTLEY B, TAYLOR SL et al. Anti-YKL-40 antibody and ionizing irradiation synergistically inhibit tumor vascularization and malignancy in glioblastoma. Carcinogenesis 2014; 35 : 373-382. https://doi.org/10.1093/carcin/bgt380

[44] KIM SH, EZHILARASAN R, PHILLIPS E, GALLEGI-PEREZ D, SPARKS A et al. Serine/Threonine Kinase MLK4 Determines Mesenchymal Identity in Glioma Stem Cells in an

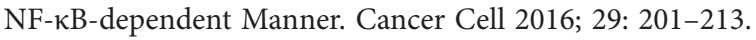
https://doi.org/10.1016/j.ccell.2016.01.005

[45] GU C, BANASAVADI-SIDDEGOWDA YK, JOSHI K, NAKAMURA Y, KURT H et al. Tumor-Specific Activation of the C-JUN/MELK Pathway Regulates Glioma Stem Cell Growth in a p53-Dependent Manner. Stem Cells 2013; 31: 870-881. https://doi.org/10.1002/stem.1322

[46] KIM SH, JOSHI K, EZHILARASAN R, MYERS TR, SIU J et al. EZH2 Protects Glioma Stem Cells from Radiation-Induced Cell Death in a MELK/FOXM1-Dependent Manner. Stem Cell Reports 2015; 4: 226-238. https://doi.org/10.1016/j. stemcr.2014.12.006

[47] DONTU G, JACKSON KW, MCNICHOLAS E, KAWAMURA MJ, ABDALLAH WM et al. Role of Notch signaling in cell-fate determination of human mammary stem/progenitor cells. Breast Cancer Res 2004; 6: R605-615. https://doi. org/10.1186/bcr920

[48] FARNIE G, CLARKE RB. Mammary stem cells and breast cancer--role of Notch signalling. Stem Cell Rev 2007; 3: 169-175. https://doi.org/10.1007/s12015-007-0023-5

[49] SHEN Y, CHEN H, ZHANG J, CHEN Y, WANG M et al. Increased Notch Signaling Enhances Radioresistance of Malignant Stromal Cells Induced by Glioma Stem/ Progenitor Cells. Plos One 2015; 10: e0142594. https://doi.org/10.1371/ journal.pone.0142594

[50] QIANG L, WU T, ZHANG HW, LU N, HU R et al. HIF- $1 \alpha$ is critical for hypoxia-mediated maintenance of glioblastoma stem cells by activating Notch signaling pathway. Cell Death Differ 2012; 19: 284-294. https://doi.org/10.1038/cdd.2011.95

[51] HU YY, ZHENG MH, CHENG GL, LIANG L, GAO F et al. Notch signaling contributes to the maintenance of both normal neural stem cells and patient-derived glioma stem cells. BMC Cancer 2011; 11: 82. https://doi.org/10.1186/14712407-11-82

[52] TCHORZ JS, TOME M, CLOETTA D, SIVASANKARAN $\mathrm{B}$, GRZMIL $\mathrm{M}$ et al. Constitutive Notch2 signaling in neural stem cells promotes tumorigenic features and astroglial lineage entry. Cell Death Dis 2012; 3: e325. https://doi.org/10.1038/ cddis. 2012.65

[53] FORTINI ME. $\gamma$-secretase-mediated proteolysis in cellsurfacereceptor signalling. Nat Rev Mol Cell Biol 2002; 3: 673-684. https://doi.org/10.1038/nrm910

[54] SELKOE D, KOPAN R. Notch and presenilin: regulated intramembrane proteolysis links development and degeneration. Annu Rev Neurosci 2003; 26: 565-597. https://doi. org/10.1146/annurev.neuro.26.041002.131334
[55] MUMM JS, KOPAN R. Notch signaling: from the outside in. Dev Biol 2000; 228: 151-165. https://doi.org/10.1006/ dbio. 2000.9960

[56] HU YY, FU LA, LI SZ, CHEN Y, LI JC et al. Hif- $1 \alpha$ and Hif- $2 \alpha$ differentially regulate Notch signaling through competitive interaction with the intracellular domain of Notch receptors in glioma stem cells. Cancer Lett 2014; 349: 67-76. https:// doi.org/10.1016/j.canlet.2014.03.035

[57] COVELLO KL, KEHLER J, YU H, GORDAN JD, ARSHAM AM et al. HIF-2 $\alpha$ regulates Oct-4: effects of hypoxia on stem cell function, embryonic development, and tumor growth. Genes Dev 2006; 20: 557-570. https://doi.org/10.1101/ gad.1399906

[58] JING W, BRESNICK EH. Bare rudiments of notch signaling: how receptor levels are regulated. Trends Biochem Sci 2007; 32: 477-485. https://doi.org/10.1016/j.tibs.2007.09.002

[59] WANG J, WAKEMAN TP, LATHIA JD, HJELMELAND AB, WANG XF et al. Notch promotes radioresistance of glioma stem cells. Stem Cells 2010; 28: 17-28.

[60] LIU RM, SUN RG, ZHANG LT, ZHANG QF, CHEN DX et al. Hyaluronic acid enhances proliferation of human amniotic mesenchymal stem cells through activation of Wnt/ $\beta$-catenin signaling pathway. Exp Cell Res 2016; 345: 218-229. https:// doi.org/10.1016/j.yexcr.2016.05.019

[61] RONG TIAN, YOU LI, XU YAO. PGRN Suppresses Inflammation and Promotes Autophagy in Keratinocytes Through the Wnt/ $\beta$-Catenin Signaling Pathway. Inflammation 2016; 39: 1387-1394. https://doi.org/10.1007/s10753-016-0370-y

[62] WANG J, LIANG Y, JIAN L, ZHANG J, LIANG S ET al. Linoelaidic acid enhances adipogenic differentiation in adipose tissue-derived stromal cells through suppression of Wnt $/ \beta$-catenin signaling pathway in vitro. Prostaglandins, Leukotrienes and Essential Fatty Acids (PLEFA) 2016; 110: 1-7. https://doi.org/10.1016/j.plefa.2016.04.004

[63] LU P, WANG Y, LIU X, WANG H, ZHANG X et al. Malignant gliomas induce and exploit astrocytic mesenchymal-like transition by activating canonical Wnt $/ \beta$-catenin signaling. Med Oncol 2016; 33: 66. https://doi.org/10.1007/s12032-016$\underline{0778-0}$

[64] WOODWARD WA, CHEN MC, BEHBOD F, ALFARO MP, BUCHHOLZ TA et al. WNT/ $\beta$-catenin mediates radiation resistance of mouse mammary progenitor cells. Proc Natl Acad Sci U S A 2007; 104: 618-623. https://doi.org/10.1073/ pnas.0606599104

[65] KIM KH, SEOL HJ, KIM EH, RHEEY J, JIN HJ et al. Wnt/ $\beta$ catenin signaling is a key downstream mediator of MET signaling in glioblastoma stem cells. Neuro Oncol 2013; 15: 161-171. https://doi.org/10.1093/neuonc/nos299

[66] DE BACCO, FRANCESCA, D'AMBROSIO, ANTONIO, CASANOVA ET al. MET inhibition overcomes radiation resistance of glioblastoma stem-like cells. EMBO Mol Med 2016; 8: 550-568. https://doi.org/10.15252/ emmm.201505890

[67] SHAHI MH, LORENTE A, CASTRESANA JS. Hedgehog signalling in medulloblastoma, glioblastoma and neuroblastoma. Oncol Rep 2008; 19: 681-688. https://doi.org/10.3892/ or.19.3.681 
[68] RUIZ I ALTABA A (Ed). Hedgehog-Gli Signaling in Human Disease. Springer-Verlag New York Inc, 2006, 228 pp. ISBN 9780387257846.

[69] TAKEZAKI T, HIDE T, TAKANAGA H, NAKAMURA H, KURATSU J et al. Essential role of the Hedgehog signaling pathway in human glioma-initiating cells. Cancer Sci 2011; 102: 1306-1312. https://doi.org/10.1111/j.13497006.2011.01943.x

[70] CLEMENT V, SANCHEZ P, TRIBOLET ND, RADOVANOVIC I, ALTABA ARI. HEDGEHOG-GLI1 signaling regulates human glioma growth, cancer stem cell self-renewal, and tumorigenicity. Curr Biol 2007; 17: 165-172. https://doi. org/10.1016/j.cub.2006.11.033

[71] CARRO MS, LIM WK, ALVAREZ MJ, BOLLO RJ, ZHAO X et al. The transcriptional network for mesenchymal transformation of brain tumours. Nature 2010; 463: 318-325. https://doi. org/10.1038/nature08712

[72] CAO Y, LATHIA JD, EYLER CE, WU Q, LI Z et al. Erythropoietin Receptor Signaling Through STAT3 Is Required For Glioma Stem Cell Maintenance. Genes Cancer 2010; 1: 50-61. https://doi.org/10.1177/1947601909356352

[73] SHERRY MM, REEVES A, WU JK, COCHRAN BH. STAT3 Is Required for Proliferation and Maintenance of Multipotency in Glioblastoma Stem Cells. Stem Cells 2009; 27: 2383-2392. https://doi.org/10.1002/stem.185

[74] YANG YP, CHANG YL, HUANG PI, CHIOU GY, TSENG $\mathrm{LM}$ et al. Resveratrol suppresses tumorigenicity and enhances radiosensitivity in primary glioblastoma tumor initiating cells by inhibiting the STAT3 axis. J Cell Physiol 2012; 227: 976-993. https://doi.org/10.1002/jcp.22806

[75] WANG L, LONG L, WANG W, LIANG Z. Resveratrol, a potential radiation sensitizer for glioma stem cells both in vitro and in vivo. J Pharmacol Sci 2015; 129: 216-225. https://doi. org/10.1016/j.jphs.2015.11.001

[76] ZHUANG W, LI B, LONG L, CHEN L, HUANG Q et al. Knockdown of the DNA-dependent protein kinase catalytic subunit radiosensitizes glioma-initiating cells by inducing autophagy. Brain Res 2011; 1371: 7-15. https://doi.org/10.1016/j. brainres.2010.11.044

[77] ZHUANG W, LI B, LONG L, CHEN L, HUANG Q et al. Induction of autophagy promotes differentiation of gliomainitiating cells and their radiosensitivity. Int J Cancer 2011; 129: 2720-2731. https://doi.org/10.1002/ijc.25975

[78] KANG KB, ZHU C, WONG YL, GAO Q, TY A et al. Gefitinib radiosensitizes stem-like glioma cells: inhibition of epidermal growth factor receptor-Akt-DNA-PK signaling, accompanied by inhibition of DNA double-strand break repair. Int J Radiat Oncol Biol Phys 2012; 83: e43-e52. https://doi.org/10.1016/j. ijrobp.2011.11.037

[79] YANG N, WANG P, WANG WJ, SONG YZ, LIANG ZQ. Inhibition of cathepsin $\mathrm{L}$ sensitizes human glioma cells to ionizing radiation in vitro through $\mathrm{NF}-\kappa \mathrm{B}$ signaling pathway. Acta Pharmacol Sin 2015; 36: 400-410. https://doi.org/10.1038/ aps.2014.148

[80] ZHANG Q, WANG J, LI J, YANG N, CHEN G et al. Cathepsin $\mathrm{L}$ suppression increases the radiosensitivity of human glioma U251 cells via G2/M cell cycle arrest and DNA damage. Acta
Pharmacol Sin 2015; 36: 1113-1125. https://doi.org/10.1038/ aps.2015.36

[81] WANG W, LONG L, WANG L, TAN C, FEI X et al. Knockdown of Cathepsin L promotes radiosensitivity of glioma stem cells both in vivo and in vitro. Cancer Lett 2015; 371: 274-284. https://doi.org/10.1016/j.canlet.2015.12.012

[82] KAO GD, JIANG Z, FERNANDES AM, GUPTA AK, MAITY A. Inhibition of phosphatidylinositol-3-OH kinase/Akt signaling impairs DNA repair in glioblastoma cells following ionizing radiation. J Biol Chem 2007; 282: 21206-21212. https://doi.org/10.1074/jbc.M703042200

[83] NARAYAN RS, FEDRIGO CA, STALPERS LJ, BAUMERT BG, SMINIA P. Targeting the Akt-pathway to improve radiosensitivity in glioblastoma. Curr Pharm Des 2013; 19: 951-957. https://doi.org/10.2174/138161213804547286

[84] MEHTA M, KHAN A, DANISH S, HAFFTY BG, SABAAWY HE. Radiosensitization of Primary Human Glioblastoma Stem-like Cells with Low-Dose AKT Inhibition. Mol Cancer Ther 2015; 14: 1171-1180. https://doi.org/10.1158/1535-7163. MCT-14-0708

[85] PAGLIN S, LEE NY, NAKAR C, FITZGERALD M, PLOTKIN $\mathrm{J}$ et al. Rapamycin-sensitive pathway regulates mitochondrial membrane potential, autophagy, and survival in irradiated MCF-7 cells. Cancer Res 2005; 65: 11061-11070. https://doi. org/10.1158/0008-5472.CAN-05-1083

[86] TAKEUCHI H, KONDO Y, FUJIWARA K, KANZAWA T, AOKI $\mathrm{H}$ et al. Synergistic augmentation of rapamycin-induced autophagy in malignant glioma cells by phosphatidylinositol 3-kinase/protein kinase B inhibitors. Cancer Res 2005; 65: 3336-3346.

[87] WENZHUO ZHUANG, BINGZONG LI, LONG L, CHEN L, HUANG Q et al. Induction of autophagy promotes differentiation of glioma-initiating cells and their radiosensitivity. Int J Cancer 2011; 129: 2720-2731. https://doi.org/10.1002/ijc.25975

[88] KAHN J, HAYMAN TJ, JAMAL M, RATH BH, KRAMP T ET al. The mTORC1/mTORC2 inhibitor AZD2014 enhances the radiosensitivity of glioblastoma stem-like cells. Neuro Oncol 2014; 16: 29-37. https://doi.org/10.1093/neuonc/not139

[89] WANG WJ, LONG LM, YANG N, ZHANG QQ, JI WJ et al. NVP-BEZ235, a novel dual PI3K/mTOR inhibitor, enhances the radiosensitivity of human glioma stem cells in vitro. Acta Pharmacol Sin 2013; 34: 681-690. https://doi.org/10.1038/aps.2013.22

[90] MAIRA SM, STAUFFER F, BRUEGGEN J, FURET P, SCHNELL $C$ et al. Identification and characterization of NVP-BEZ235, a new orally available dual phosphatidylinositol 3-kinase/mammalian target of rapamycin inhibitor with potent in vivo antitumor activity. Mol Cancer Ther 2008; 7: 1851-1863. https://doi.org/10.1158/1535-7163.MCT-08-0017

[91] MUKHERJEE B, TOMIMATSU N, AMANCHERLA K, CAMACHO CV, PICHAMOORTHY N et al. The Dual PI3K/mTOR Inhibitor NVP-BEZ235 Is a Potent Inhibitor of ATM- and DNA-PKCs-Mediated DNA Damage Responses. Neoplasia 2012; 14: 34-43. https://doi.org/10.1593/neo.111512

[92] YANG W, SHEN Y, WEI J, LIU F. MicroRNA-153/Nrf-2/GPx1 pathway regulates radiosensitivity and stemness of glioma stem cells via reactive oxygen species. Oncotarget 2015; 6: 22006-22027. https://doi.org/10.18632/oncotarget.4292 
[93] YANG W, YU H, SHEN Y, LIU F, YANG Z ET AL. MiR-146b$5 p$ overexpression attenuates stemness and radioresistance of glioma stem cells by targeting HuR/lincRNA-p21/3-catenin pathway. Oncotarget 2016; 27: 41505-41526. https://doi. org/10.18632/oncotarget.9214

[94] CONTI A, AGUENNOUZ M, TORRE DL, TOMASELLO C, CARDALI S ET AL. miR-21 and 221 upregulation and miR$181 \mathrm{~b}$ downregulation in human grade II-IV astrocytic tumors. J Neurooncol 2009; 93: 325-332. https://doi.org/10.1007/ s11060-009-9797-4

[95] GALH, PANDI G, KANNER AA, RAMZ, LITHWICK-YANAI $\mathrm{G}$ et al. MIR-451 and Imatinib mesylate inhibit tumor growth of Glioblastoma stem cells. Biochem Biophys Res Commun 2008; 376: 86-90. https://doi.org/10.1016/j.bbrc.2008.08.107

[96] MA J, YAO Y, WANG P, LIU Y, ZHAO L ET AL. MiR-152 functions as a tumor suppressor in glioblastoma stem cells by targeting Krüppel-like factor 4. Cancer Lett 2014; 355: 85-95. https://doi.org/10.1016/j.canlet.2014.09.012

[97] SILBER J, LIM DA, PETRITSCH C, PERSSON AI, MAUNAKEA AK et al. miR-124 and miR-137 inhibit proliferation of glioblastoma multiforme cells and induce differentiation of brain tumor stem cells. BMC Med 2008; 6: 14. https://doi. org/10.1186/1741-7015-6-14

[98] CHALMERS AJ. Radioresistant glioma stem cells-Therapeutic obstacle or promising target? DNA Repair 2007; 6: 1391-1394. https://doi.org/10.1016/j.dnarep.2007.03.019
[99] WU J, LAI G, WAN F, XIAO Z, ZENG L et al. Knockdown of checkpoint kinase 1 is associated with the increased radiosensitivity of glioblastoma stem-like cells. Tohoku J Exp Med 2012; 226: 267-274. https://doi.org/10.1620/tjem.226.267

[100] ZHOU W, SUN M, LI GH, WU YZ, WANG Y et al. Activation of the phosphorylation of ATM contributes to radioresistance of glioma stem cells. Oncol Rep 2013; 30: 1793-1801.

[101] VECCHIO D, DAGA A, CARRA E, MARUBBI D, BAIO G et al. Predictability, efficacy and safety of radiosensitization of glioblastoma-initiating cells by the ATM inhibitor KU-60019. Int J Cancer 2014; 135: 479-491. https://doi.org/10.1002/ ijc. 28680

[102] YI CL, ROBERTS TL, DAY BW, STRINGER BW, KOZLOV $S$ et al. Increased sensitivity to ionizing radiation by targeting the homologous recombination pathway in glioma initiating cells. Mol Oncol 2014; 8: 1603-1615. https://doi.org/10.1016/j. molonc.2014.06.012

[103] SAI S, WAKAI T, VARES G, YAMADA S, KAMIJO T et al. Combination of carbon ion beam and gemcitabine causes irreparable DNA damage and death of radioresistant pancreatic cancer stem-like cells in vitro and in vivo. Oncotarget 2015; 6: 5517-5535. https://doi.org/10.18632/oncotarget.3584

[104] SAI S, VARES G, KIM EH, KARASAWA K, WANG B et al. Carbon ion beam combined with cisplatin effectively disrupts triple negative breast cancer stem-like cells in vitro. Mol Cancer 2015; 14: 166. https://doi.org/10.1186/s12943-015-0429-7 